\title{
Climate change: an amplifier of existing health risks in developing countries.
}

Citation for published version (APA):

Huynen, M., \& Martens, P. (2013). Climate change: an amplifier of existing health risks in developing countries. Environment, Development and Sustainability, 5, 1425-1442. https://doi.org/10.1007/s10668013-9450-4

Document status and date:

Published: 01/01/2013

DOI:

10.1007/s10668-013-9450-4

Document Version:

Publisher's PDF, also known as Version of record

Document license:

Taverne

Please check the document version of this publication:

- A submitted manuscript is the version of the article upon submission and before peer-review. There can be important differences between the submitted version and the official published version of record.

People interested in the research are advised to contact the author for the final version of the publication, or visit the DOI to the publisher's website.

- The final author version and the galley proof are versions of the publication after peer review.

- The final published version features the final layout of the paper including the volume, issue and page numbers.

Link to publication

\footnotetext{
General rights rights.

- You may freely distribute the URL identifying the publication in the public portal. please follow below link for the End User Agreement:

www.umlib.nl/taverne-license

Take down policy

If you believe that this document breaches copyright please contact us at:

repository@maastrichtuniversity.nl

providing details and we will investigate your claim.
}

Copyright and moral rights for the publications made accessible in the public portal are retained by the authors and/or other copyright owners and it is a condition of accessing publications that users recognise and abide by the legal requirements associated with these

- Users may download and print one copy of any publication from the public portal for the purpose of private study or research.

- You may not further distribute the material or use it for any profit-making activity or commercial gain

If the publication is distributed under the terms of Article $25 \mathrm{fa}$ of the Dutch Copyright Act, indicated by the "Taverne" license above, 


\title{
Climate change: an amplifier of existing health risks in developing countries
}

\author{
Maud M. T. E. Huynen · Pim Martens $\cdot$ Su-Mia Akin
}

Received: 14 November 2012/Accepted: 11 March 2013/Published online: 22 March 2013

(C) Springer Science+Business Media Dordrecht 2013

\begin{abstract}
Global warming is perceived as one of the biggest global health risks of the twenty-first century and a threat to the achievement of sustainable (economic) development; especially in developing countries, climate change is believed to further exacerbate existing vulnerability to disease and food security risks, because their populations are, for example, more reliant on agriculture and more vulnerable to droughts and have a lower adaptive capacity. Furthermore, the health-related impacts of climate change are threatening to undo decades of development policies. The interactions between climate and nonclimate factors are of vital importance in shaping human vulnerability to global warming. Climate change cannot be seen as 'a stand-alone risk factor,' but rather as an amplifier of existing health and food security risks and an additional strain on institutional infrastructures. In order to avoid a multiplication of health risks in the developing world, there is a need to better understand the multifaceted and complex linkages involved. This is further illustrated for two important climate change-induced health risks, namely malnutrition and malaria. As the amplification of existing and emerging health risks in the developing world might become the greatest tragedy of climate change, adaptation ranks high on developing countries' agendas. Of particular importance are the discussions about the 'Green Climate Fund,' which aims to administer billions of dollars for mitigation and adaptation. Of course, making funds for adaptation available is an important first step, but we also need to ask ourselves the question how such adaptation policies and projects should take shape. This paper demonstrates that an adequate response to climate change health risks should take a systems approach toward adaptation, acknowledging the importance of the local context of the most vulnerable.
\end{abstract}

Keywords Climate change $\cdot$ Health $\cdot$ Developing countries $\cdot$ Malaria $\cdot$ Food security Malnutrition · Vulnerability

M. M. T. E. Huynen $(\bowtie) \cdot$ P. Martens · S.-M. Akin

International Centre for Integrated Assessment and Sustainable Development (ICIS),

Maastricht University, P.O. Box 616, 6200 MD Maastricht, The Netherlands

e-mail: m.huynen@maastrichtuniversity.nl 


\section{Introduction}

Climate change is only one of many health determinants (Ebi et al. 2011). At the same time, it is perceived as one of the most important future health risks (Costello et al. 2009) and a threat to the achievement of sustainable (economic) development (World Bank 2009). This can be explained by the fact that climate change can act as an important amplifier of existing health and food security risks, particularly in developing regions.

The Intergovernmental Panel on Climate Change (IPCC 2007b) states that global greenhouse gas (GHG) emissions have grown significantly since pre-industrial times, with a very strong increase since 1970. Although some uncertainties remain about the sensitivity of the global climate system to changes in GHG concentrations and about the future trajectories of these concentrations, there is now near-unanimous scientific agreement that the rising GHG concentrations will cause additional warming and other climatic changes (including a change in climatic variability) over coming decades (Canfalonieri and McMichael 2006; IPCC 2007b). According to the IPCC's fourth assessment report (2007b), the expected increase in global mean temperature is between 1.1 and $6.4{ }^{\circ} \mathrm{C}$ for the year 2100 , with best estimates between 1.8 and $4.0{ }^{\circ} \mathrm{C}$ (see also Table 1). This prospect of global warming has prompted increasing concern about its health impacts, including impacts on heat stress, flooding, infectious diseases, sanitation and water security, air quality (including aeroallergens such as pollen), and food security (McMichael et al. 2003, 2006; IPCC 2007a; Comrie 2007). A joint report by The Lancet and University College London (Costello et al. 2009) stressed that "climate change is the biggest global health threat of the twenty-first century,' as its impacts 'will affect most populations in the next decades and put the lives and wellbeing of billions of people at increased risk.'

The World Health Organization's (WHO) Global Burden of Disease Project has estimated that climate change has been responsible for 5.5 million disability-adjusted life years lost in 2000 (WHO 2002), with developing countries bearing a disproportionately high share of this disease burden (McMichael et al. 2004). Climate change impacts on health are of particular concern for the developing world, as global warming is believed to further exacerbate the already existing vulnerabilities to disease risk and malnutrition. Developing countries will experience the effects of climate change differently, not only because of differences in the projected change of climate parameters but also because nonclimate factors vary greatly between nations and regions (Mertz et al. 2009). Their populations are, for example, more reliant on agriculture and more vulnerable to droughts and

Table 1 Projected global average surface warming at the end of the twenty-first century for the SRES scenarios B1, A1T, B2, A1B, A2, and A1F (IPCC 2007b)

a For more information about the SRES scenarios, see IPCC (2000)

\begin{tabular}{lll}
\hline SRES scenario $^{\mathrm{a}}$ & \multicolumn{2}{l}{$\begin{array}{l}\text { Temperature change }\left({ }^{\circ} \mathrm{C} \text { at } 2090-2099 \text { relative to }\right. \\
1980-1999)\end{array}$} \\
\cline { 2 - 3 } & Best estimate & Likely range \\
\hline B1 & 1.8 & $1.1-2.9$ \\
A1T & 2.4 & $1.4-3.8$ \\
B2 & 2.4 & $1.4-3.8$ \\
A1B & 2.8 & $1.7-4.4$ \\
A2 & 3.4 & $2.0-5.4$ \\
A1FI & 4.0 & $2.4-6.4$ \\
\hline
\end{tabular}


have a lower adaptive capacity (USGCRP 2008). Furthermore, it has been argued by the World Bank (2009) that unmanaged climate change will reverse important development progress in developing countries.

In the remainder of this paper, we argue that vulnerability to climate change impacts should be seen within the broader system of health determination, including many nonclimate factors. Taking such a systems perspective on health demonstrates that the interactions between climate and non-climate factors are of vital importance in shaping the high vulnerability to the adverse impacts of global warming in developing nations. This is further illustrated for two important climate change-induced health risks, namely malaria and malnutrition. Both of these health issues are already contributing greatly to the disease burden in the developing world (WHO 2002, 2011; FAO 2010), negatively affecting development progress. Not surprisingly, lowering the number of malaria cases and halving hunger by 2015 are important Millennium Development Goals (UN 2012b). While there has been some promising progress in tackling malaria (UN 2012b), the observed declines in incidence and mortality are falling short of the ambitious Global Malaria Action Plan goals of reducing global malaria cases by $75 \%$ and preventable global malaria deaths to near-zero in 2015 (RBM Partnership 2008; UN 2012b). Progress in relieving food deprivation has even slowed or stalled in many regions (FAO 2010; UN 2012b). For both selected health effects, we will examine in more detail some important linkages between climate and non-climate factors that are crucial in determining the vulnerability context in the face of global warming. Finally, we conclude that understanding and addressing the interdependencies between factors that create a higher vulnerability to adverse health impacts is central in formulating adequate climate change adaptation policies.

\section{A systems perspective on vulnerability to climate change health impacts}

The IPCC (2007a) defines vulnerability as 'the degree to which a system is susceptible to, and unable to cope with, adverse effects of climate change.' It is the outcome of the complex interplay between the exposure to the hazard (i.e., the character, magnitude and rate of climate change, and variation to which a system is exposed), the sensitivity to the hazard, and the capacity to adapt (Adger and Winkels 2007; IPCC 2007a). This means that human vulnerability to the adverse health effects of global warming depends not only on the extent and magnitude of climate change, but also on the characteristics of and developments in the associated natural and human systems (Ebi 2009). As such, global warming affects health through extensive and complex linkages between a multitude of factors, which together determine the vulnerability context of a specific population.

This is in line with the increasing interest in multilevel and systems approaches to population health (McMichael 1995, 1999; Pearce 2004; Pearce and Merletti 2006). An ever-growing number of health researchers (Pearce and Merletti 2006; Albrecht et al. 1998; Colwell 2004; Wilcox and Colwell 2005; McMichael 2005; Huynen et al. 2005a; Huynen 2008) argue that the health of a population must be viewed within the broader system of health determinants. Risk factors for disease, such as global warming, do not operate in isolation, but occur in a particular population context. In order to illustrate this broader context or system of population health, Huynen (2008) and Huynen et al. (2005a, b) developed a basic framework that conceptualizes the complex multicausality of population health by combining the nature of health determinants and their level of causality. To differentiate between determinants of a different nature, their framework makes the customary distinction between institutional, sociocultural, economic, and environmental 
determinants. These determinants operate at different hierarchical levels of causality. The chain of events leading to a specific health outcome includes both proximal and distal causes-proximal factors act directly to cause disease or health gains, while distal determinants are set further back in the causal chain and act via intermediate causes. In addition, contextual determinants also play an important role. These can be seen as the upstream macrolevel conditions shaping the distal and proximate health determinants; they form the context within which the distal and proximate factors operate and develop. Figure 1 shows the wide-ranging overview of the health determinants that can fit within this framework, including the processes of global environmental change such as global warming. The way different factors and developments within the system interact is critical to how the whole system works and, subsequently, how vulnerable populations are to a particular health risk.

Various terms have been used to describe such broader approaches to population health, such as eco-epidemiology (Martens 1998; Susser and Susser 1996; Ladd and Soskolne 2008; Soskolne and Broemling 2002), ecological perspective on health (McLaren and Hawe 2005), socioecological systems perspective on health (McMichael 1999), ecosystem approach to public health (Arya et al. 2009), ecological pubic health (Morris 2010), and biocomplexity approach to health (Colwell 2004; Wilcox and Colwell 2005). As Soskolne et al. (2007) state, we 'must embrace greater complexity' as 'the traditionally used, reductionist, linear approaches are inferior for understanding the interactive webs that are critical for sustainable development and for the health and well-being of future generations.' Similarly, the WHO (2009) argues that systems thinking works to reveal the underlying characteristics and relationships of population health systems.

Taking such broader approach toward population health, it becomes clear that the interactions between climate and non-climate factors are crucial in shaping human vulnerability to the adverse health impacts of global warming. Through these system interactions, climate change can often act as an important amplifier of existing health and food

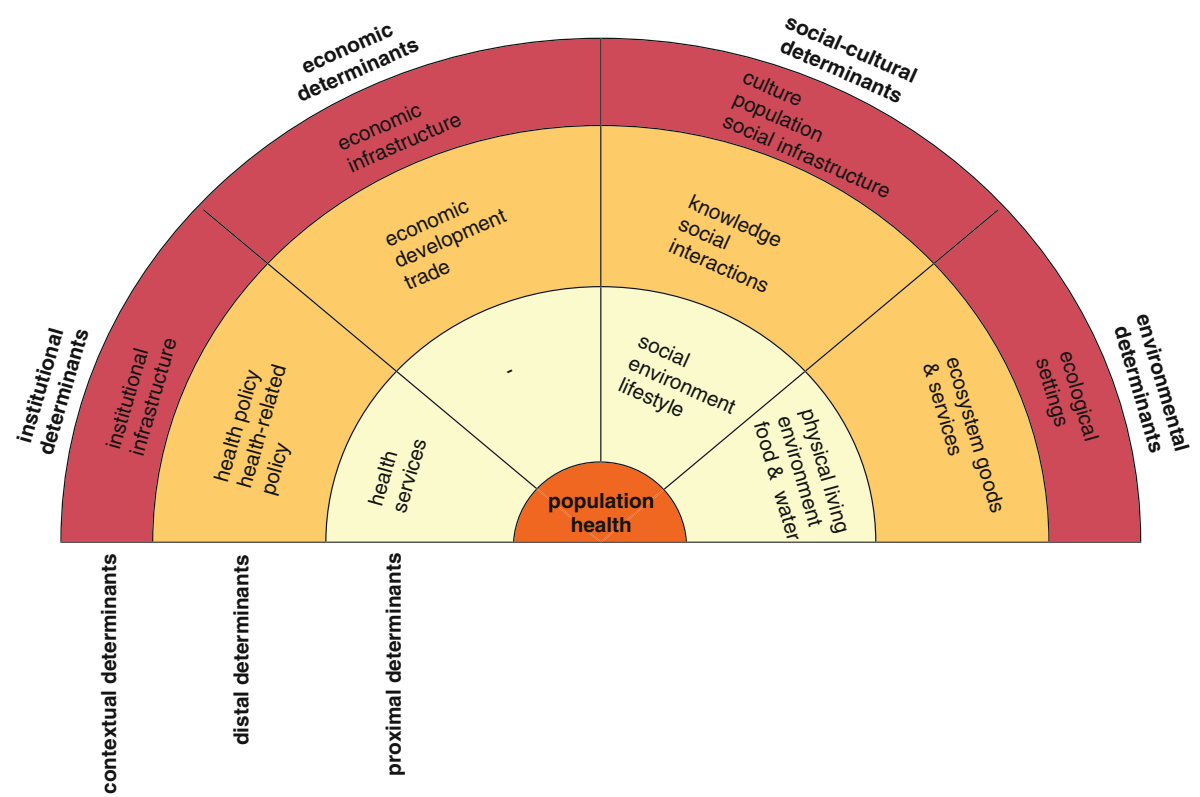

Fig. 1 Multinature and multilevel framework for population health, developed by Huynen et al. (2005a) 
security risks (Costello et al. 2009), in particular in developing regions. Hence, tackling the high vulnerability of developing countries requires a careful exploration of the bigger picture involved.

Although this paper mainly focuses on the high vulnerability of developing countries, it is important to note that the need for a systems perspective toward the health impacts of global warming is also starting to be recognized in developed countries. An advisory report by the Health Council of the Netherlands (Gezondheidsraad 2009), for example, concluded that Dutch research in this field needs to adopt systems thinking in order to account for the multiple interactions that affect public health. Similarly, Berrang-Ford et al. (2009) call for a systems approach in assessing the combined effect of climate and non-climate determinants of malaria risk in Canada, accounting for the fact that climate change may have indirect effects on Canadian malaria incidence by affecting the non-climate determinants of transmission.

\section{Climate change as an amplifier of food insecurity}

As most food-insecure countries are located in Asia and sub-Saharan Africa (FAO 2011b), the impacts of climate change on the-already highly stressed-agro-food systems are of particular concern for developing countries in these regions (HLPE 2012). The FAO (2010) estimated that in 2010 the total number of undernourished people was about 925 million; the majority of these undernourished people live in developing countries. In his address to the World Summit for Food Security in 2009, U.N. Secretary-General Ban Kimoon stressed that six million children die of hunger every year-17,000 every day. Progress is lacking in achieving the international commitment of halving hunger by 2015 (UN 2012b). The UN (2009) argues that food production must double by 2050 in order to meet the growing demand.

Food security is typically defined as 'when all people, at all times, have physical and economic access to sufficient, safe and nutritious food to meet their dietary needs and food preferences for an active and healthy life.'(FAO 1996b). The overall scientific consensus is that climate change is likely to increase the number of people at risk of hunger, especially in Asia and sub-Saharan Africa (IPCC 2007a). The High Level Panel of Experts on Food Security and Nutrition (HLPE 2012) views climate change as one of the greatest challenges for food security. Climate change affects food security in various ways, and its impacts will vary greatly across different geographical regions (IPCC 2007a). Most simulation studies focus on the impacts of changes in the general climate on food production and availability (Schmidhuber and Tubiello 2007; IPCC 2007a). Optimist might highlight the IPCC's (2007a) conclusion that these modeling studies show that the potential for global food production is expected to increase with moderate increases $\left(1-3^{\circ} \mathrm{C}\right)$ in local average temperature. A closer look at this 2007 IPCC report reveals, however, that the underlying model simulations indeed show an increase in crop yields at high and mid-latitudes, but a decline with even minimal warming at seasonally dry and low latitudes (in particular cereals). The model outcomes, additionally, show that further warming $\left(>3{ }^{\circ} \mathrm{C}\right)$ will negatively affect food production in all regions.

It has been argued that the model simulations are too optimistic about yield improvements with moderate warming. Lobell and Field (2007) showed that in the period 1981-2002 there was an observed negative response of wheat, maize, and barley yields to rising temperature (Lobell and Field 2007). Possible nonlinearity of the temperature response is also not taken into account. Moreover, it is important to realize that potential 
impacts of climate change on pests and diseases, air pollution, the magnitude of the $\mathrm{CO}_{2}$ response, variability in climate, and climate extremes are not always adequately addressed in simulation models, because they are not well understood (Ainsworth and Ort 2010; IPCC 2007a). For example, the IPCC (2007a) acknowledges that possible changes in frequency and severity of extreme events are believed to have more serious consequences for food security than changes in mean temperature. Major crop yield losses were reported in summer 2003, when Europe experienced an extreme heat wave and an annual precipitation $50 \%$ below average (Ciais et al. 2005). Such extreme events are not well characterized in the IPCC assessment simulations (IPCC 2007a). It has also been argued, for example, that model simulations are too optimistic about the magnitude of the $\mathrm{CO}_{2}$ response; the actual $\mathrm{CO}_{2}$ fertilization response of crops could be only half that expected (Long et al. 2006) and currently used in simulation models (Ainsworth and Ort 2010; Nellemann et al. 2009). Current research results conclude that while crops would respond positively to elevated $\mathrm{CO}_{2}$ in the absence of climate change, the associated impacts of high temperatures, altered patterns of precipitation, and possible increased frequency of extreme events such as droughts and floods will likely combine to adversely affect yields and raise production risks in many world regions (Tubiello and Fischer 2006). Perhaps even more important is the modeling assumptions on adaptation. Some studies do not account for adaptation (Long et al. 2006), while others assume that a full range of adaptation strategies is available in different regions (Howden et al. 2007). Within the context of a developing country, though, adaptive capacity is often lower, so it is here that climate change can potentially pose challenges and create uncertainties for agricultural production and productivity.

Sufficient agricultural productivity is, however, not the only component of food security. It is widely accepted that food security is a multidimensional concept, including availability, access, utilization (including food safety), and stability. As such, food (in)security is driven by complex underlying systems, in which a suitable climate is only one of the many interacting factors involved (Hammond and Dubé 2012). For example, sub-Saharan Africa is currently highly vulnerable to food insecurity due to the interplay of important current-day stressors such as drought conditions, flooding, pest outbreaks, poverty, impaired health status (malaria, HIV), and increasing food prices, while at the same time current response options are constrained by, for example, lack of information, ineffective institutional infrastructures, corruption, and international neoliberal policies (IPCC 2001). Global warming is believed to affect all of the four dimensions of food security (see Table 2 for examples), adding to the already complex 'food security' equation. Consequently, the vulnerability to climate impacts on food security, food safety, and malnutrition is highly dependent on non-climate factors within this system. We will explore this in more detail by highlighting the interlinkages between climate change, food security, food trade, and food prices.

The fragility of the global agro-food system became very evident during the world food crisis of 2007-2008, which highlighted that global trade and developments in food prices on the world markets have become an increasingly important factor with regard to food security worldwide. Some argue that free trade creates access to better and cheaper food supplies via food imports and can stimulate more efficient use of the world's resources, as well as the production of food in regions that are more suitable to do so (FAO 1996a, 2003a). On the other hand, trade could also significantly endanger food security (e.g., Lang (1996)). Many food-insecure countries are not able to earn enough with exporting goods in order to pay for the needed food imports (FAO 2003b, 2011b). The agricultural sector of developing countries has changed dramatically over the past decades due to global market 
Table 2 Anticipated impacts of climate change on food security (Ainsworth and Ort 2010; Schmidhuber and Tubiello 2007; IPCC 2007a)

\begin{tabular}{|c|c|}
\hline Food security dimension* & Examples of anticipated climate change impacts \\
\hline Food availability & $\begin{array}{l}\text { - Climate change can directly affect food availability via its impacts on agro- } \\
\text { ecological conditions and associated impacts, e.g.: } \\
\text { Changes in temperature and precipitation can impact on land } \\
\text { suitability and crop yields } \\
\text { Climate change can induce geographical expansion of crop pests, as } \\
\text { well as enhance winter survival of pest populations } \\
\text { - Higher atmospheric } \mathrm{CO}_{2} \text { concentration can affect biomass accumulation and, } \\
\text { consequently, crop yield. }\end{array}$ \\
\hline Access to food & $\begin{array}{l}\text { - Climate change can affect physical, economic and social access to food via } \\
\text { declining agricultural production, rising food prices and declining purchasing } \\
\text { power due to contraction of agricultural income. }\end{array}$ \\
\hline Food utilization & $\begin{array}{l}\text { - Climate change can affect the conditions of food safety and disease pressure } \\
\text { from vector, water and food-borne diseases } \\
\text { increases in temperature could possibly affect the safety of the } \\
\text { available food supplies (e.g. increasing the frequency of food } \\
\text { poisoning). } \\
\text { Malaria affects the proper absorption of nutrients by the body and, } \\
\text { consequently, effects the biological utilization of food. }\end{array}$ \\
\hline Food stability & $\begin{array}{l}\text { - Climate change can affect stability via its impacts on global and regional } \\
\text { weather conditions } \\
\circ \quad \text { Increasing frequency of extreme weather events (e.g. cyclones, } \\
\text { floods, hailstorms, droughts, heat waves) can result in greater } \\
\text { fluctuations in crop yields and (local) food supplies }\end{array}$ \\
\hline
\end{tabular}

processes and policies, and many developing countries have been turned from self-sufficient entities into net importers. For many countries, this growing dependence on food imports increases their vulnerability to shocks arising in global markets, which can affect import capacity and access to food imports for basic consumption (FAO 1996a, 2008, 2011b).

This is exactly what happened in 2007-2008. The prices of some of the most basic international food commodities soared on international markets, after decades of declining international food prices (Nellemann et al. 2009; FAO 2008, 2011b). The causes behind the observed rise in food prices are wide-ranging and complex, including (FAO 2008, 2009b; Heady and Fan 2008):

- High oil prices: The higher price for oil affected not only the costs of the energy used in agricultural production (e.g., electricity), but also the costs of fertilizers and transportation. Indirectly, higher oil prices can push food prices upward by enhancing the demand for biofuels.

- Increased biofuel production: The emerging demand for biofuel and the consequent increase in its production is believed to have distorted food markets, as it diverted important commodities (e.g., maize, some oil seeds, and soybeans) away from food to fuel. Moreover, the growth in biofuel production has put stress on the available fertile land resources. Hence, the developments in the international biofuel market have been linked to (part of) the observed increase in food prices.

- Weather shocks in grain-producing regions: Weather conditions (e.g., droughts) caused cereals production shortfalls in 2005-2006 in major exporting countries such as Australia and the U.S.A. Although similar weather-related production shortfalls have been observed before (e.g., in 2000/2001 and 1992/1994), the failing wheat harvests in 
the mid-2000s significantly interacted with other developments such as lower buffer stocks (see below) and increased market sensitivity. It has been argued, hence, that the observed weather-related production shortfalls have been a critical trigger for the increasing food prices.

- Depreciation of the US Dollar: The depreciation of the US dollar worsened prior to the food crisis, and most likely increased dollar-denominated prices in the food market.

- Decreasing stocks: The stocks of all major cereals have seen great declines prior to the food crisis. Such stock declines affect price volatility by determining the stability of supply. However, the association between the observed stock declines and the increasing food prices needs to be interpreted with some caution about the underlying causality, partly because the stock declines themselves are probably the result of deeper causes (e.g., demand for biofuels, bad weather) and partly because their price effects are mediated by other factors (e.g., exacerbating shocks).

- Export restrictions: In late 2007 and early 2008, several countries (accounting for $40 \%$ of the global rice export) imposed trade restrictions for rice, resulting in a subsequent sharp increase of $140 \%$ in rice prices between November 2007 and March 2008. However, these export restrictions cannot be seen as a driver for the (earlier) price increases in, for example, wheat, maize, and soybeans.

- Financial speculation in agricultural commodities (e.g., grains): The rise in food prices coincided with greater financial market activity, as speculators have been drawn to invest in agricultural derivatives. The resulting demand pressures are believed to have driven market prices up as well as facilitated greater volatility. It has been argued, however, that the increased financial speculation should not be seen as a primary driver of the rising food prices (i.e., the higher food prices possibly induced speculation), but as a mediating factor that further enhanced the global food crisis.

During the 2007-2008 food crisis, the number of hungry and malnourished people rose dramatically (FAO 2009a), and the progress made so far in achieving the hunger target of the Millennium Development Goals came under severe threat. Vulnerability to the observed surging food prices varied between different groups of countries and people, with low-income, net importing countries with already higher levels of chronic hunger and/or undernourishment being among the most vulnerable (FAO 2008, 2011b). The high prices have had a dramatic and disproportional impact on the lives and livelihoods of those already undernourished or living in poverty (Nellemann et al. 2009). Many of the least developed countries have become increasingly dependent on imported food in recent decades, while their export sectors are unable to generate enough revenues to pay for these food imports (FAO 2011b). This has important consequences for their populations' access to food on the global markets, in particular in times of drastic price increases. Hence, many poor import-dependent countries, especially in Africa, were deeply affected by the food crisis. On the other hand, the higher international food prices benefited countries that were net food sellers, as their agricultural income increased despite the higher costs for fuel and fertilizers (e.g., Vietnam, Thailand). Likewise, higher food prices substantially harm poor net food buyers at the household level, who already spend a large majority of their income on food, such as the urban poor, small-scale farmers, and agricultural laborers. Additionally, regions that experienced declining food production due to drought conditions also faced a consequent loss in the agricultural income of their farmers. Farmers and landowners with surplus production (over and above subsistence food production) to sell benefited from the high prices (FAO 2011b). 
From the above, it becomes evident that the food crisis was the result of the complex interplay between a multitude of developments. But even though the falling agricultural production due to weather conditions was only one of the many factors involved, it played an important role in (further) destabilizing an extremely vulnerable agro-food system. According to the FAO (2011a), greater attention is now being given to climate changes as one of the drivers of the global food crisis. Besides affecting agricultural production, climate change also harms the livelihoods of those already vulnerable to food insecurity (HLPE 2012) and could further worsen the safety of scarce food supplies (Schmidhuber and Tubiello 2007). Additionally, the distortion caused by the increasing demand for biofuels can also be seen as climate related, as an increasing number of countries (e.g., the European Union) have announced biofuel subsidies, mandates, and targets as part of their climate change mitigation policies. For the future, the FAO (2009a, 2011b) acknowledges that climate change and increased biofuel production represent major risks for long-term food security. These factors will continue to pose substantial challenges to producing food at affordable prices (FAO 2011b; Brown and Funk 2008; HLPE 2012).

The IPCC (2007a) anticipates that food trade will further increase in response to future climate change, due to geographical shifts in agricultural production; rising exports of temperate zone food products to tropical countries are expected, as well as increased dependence on food imports for most developing countries. Additionally, increasing demands for biofuels will continue to spur competition between food and energy commodities for the limited land and water resources, driving food prices even further upward (Nellemann et al. 2009; FAO 2009a). The least developed countries will also be faced with low adaptive capacities to respond to these climate change (mitigation) pressures on their food security (Iglesias et al. 2011). Hence, the interplay between climate change impacts, food production, demand for biofuels, poverty, food trade, and food prices contributes significantly to the high vulnerability of developing countries to (future) global warming, in particular in sub-Saharan Africa.

\section{Climate change as an amplifier of malaria risk}

Malaria is a life-threatening disease caused by Plasmodium parasites that are transmitted to people through the bites of infected mosquitoes. In the last decade, important declines in malaria incidence and mortality have been observed, mainly attributed to the huge increase in funding for malaria control and elimination programs (Pigott et al. 2012). Nevertheless, about 3.3 billion people - half of the world's population - are currently at risk of malaria. According to the World Malaria Report 2011 (WHO 2011), there were about 216 million cases of malaria and an estimated 655,000 deaths in 2010. Others (Murray et al. 2012) have recently suggested that mortality rates are even substantially higher. People living in the poorest countries are the most vulnerable to malaria; the WHO (2011) estimates that $90 \%$ of all malaria deaths in 2010 occurred in Africa. And even though mortality rates have fallen by more than $33 \%$ in the WHO African Region since 2000, the disease still kills one African child every minute (WHO 2011).

Climate (change) is believed to be an important factor in the dynamics of malaria transmission (Martens et al. 1999; Chaves and Koenraadt 2010; IPCC 2007a). For example, temperature affects mosquito survival as well as parasite development. Additionally, mosquito survival is also affected by changes in humidity, while developments in rainfall (patterns) can affect the number of suitable breeding sites. Most simulation studies focus on the impacts of changes in the general climate on potential shifts in distribution 
and magnitude of endemic malaria in at-risk regions and on changes in regions at the margins of current endemic distributions (IPCC 2007a). The health-impact models are typically based on climatic constraints on the development of the vector and/or parasite (IPCC 2007a). Some model studies (e.g., Martens et al.(1999), Ermert et al.(2012)) indicate a significant change in areas suitable for malaria mosquitoes or in malaria transmission; others (Rogers and Randolph 2000) conclude that climate change will not result in any significant net change in malaria risk. In projections by Gething et al. (2010), the risk was even found to decline by 2050 due to control measures.

There are several approaches that are used to model malaria. Multivariate statistical techniques can be used to select predictive variables (Rogers and Randolph 2000). Taking a different approach, process-based biological models are based on the formula for the basic reproduction rate (Ro) to calculate the 'transmission or epidemic potential' of a malaria-mosquito population. Model variables within Ro that are sensitive to temperature include mosquito density, feeding frequency, survival, and extrinsic incubation period, with the minimum temperature for parasite development being the limiting factor for malaria transmission in many areas. Results of studies that combine such biological models with climate change scenarios show shifts in malaria risk with global warming (Martens et al. 1995, 1999; van Lieshout et al. 2004; Ermert et al. 2012).

All approaches have their specific disadvantages and advantages. For example, the model developed by Rogers and Randolph (2000)—based on multivariate statistical techniques-incorporates information about the current social, economic, and technological modulation of malaria transmission. As such, however, it is automatically assumed that those contextual factors will apply in the future in unchanged fashion (Martens and Thomas 2005). However, the parameters estimated by such models are useful to gain a further understanding of disease transmission, but they need to be presented with more caution based on the stability of the system under future change (Chaves and Koenraadt 2010). Additionally, the same study has been criticized for using current distribution limits in their estimate; this may have yielded a biased estimation of the multivariate relationship between climatic variables and malaria occurrence, since the lower temperature range in temperate zones would have been treated as climatically unsuitable for malaria (Martens and Thomas 2005). The biological model of Martens et al. $(1995,1999)$ assumes that there are known and generalizable biologically mediated relationships. Also, this type of modeling is only making a start to include the horizontal integration of social, economic, and technical change (Martens and Thomas 2005; van Lieshout et al. 2004).

Based on the outcomes of several modeling studies, the IPCC (2007a) concludes that climate change will have mixed effects on malaria; some places will experience a reduction in its geographical range, while other locations will see an expanding geographical range and a changing transmission season. The IPCC report also stresses that, despite the known causal links between climate and malaria transmission dynamics, the anticipated future impacts on disease risk are still surrounded by uncertainty, partly due to the fact the relationship between vector-borne disease incidence and climate variables is complicated by many non-climate factors. The models so far have only included limited non-climate assumptions (IPCC 2007a) and forecasts can be very imprecise due to the sensitivity of nonlinear multidimensional systems to all of their underlying dynamics and interactions, especially those that are not accounted for by the studied models (Chaves and Koenraadt 2010).

Consequently, the search for alternative malaria drivers has become one of the major fields of inquiry (Chaves and Koenraadt 2010). In an elaborate literature review, Cohen et al. (2012) identified the following suggested causes of past malaria resurgence events: 
weakening of control activities (e.g., due to funding constraints, poor execution, purposeful cessation), technical problems (e.g., vector resistance, drug resistance), human or mosquito movement, development/industry changes (including land use change), socioeconomic weakening, climate/weather, and war. Malaria is also closely linked to poverty; poorer communities have a higher disease risk due to, for example, lower (financial) access to health services, poorer nutritional status, lower education levels, poor sanitation, and inadequate housing (Ricci 2012). Although the above listing is probably far from exhaustive, it clearly illustrates that climate change is just one of many processes that affect infectious disease risk (Morse 1995; Cohen 2000; Sutherst 2004; McMichael 2004). Hence, the assessment of climate change impacts on malaria is challenged by the complex interactions between climate and non-climate factors. We will explore this in more detail by looking at the various drivers of malaria emergence in the East African highlands.

Malaria in East Africa's highlands presents a case study for understanding the challenges that climate change poses to Africa (Tesi 2011). Historically, the high altitudes of the African highlands and the associated lower temperatures have functioned as a shelter against malaria. However, the numerous reports of increased malaria down the East African highland chain showed that malaria is becoming established in regions that belong to these territorial margins of its previous distributions (Lindsay and Martens 1998; Himeidan and Kweka 2012; Tesi 2011; Chaves and Koenraadt 2010). The IPCC (2007a), for example, explicitly expressed its concern about future climate change impacts on malaria risk in the highlands of East Africa. A recent study by Ermert et al. (2012) concluded that climate changes will significantly affect the spread of malaria in tropical Africa well before 2050, with a changing geographical distribution of areas where malaria is epidemic (e.g., highlands) in the coming decades.

In the past two decades, there has been some debate about the importance of climate change in driving observed changes in malaria distribution and transmission in highland regions (IPCC 2007a; Chaves and Koenraadt 2010), and other alternative drivers have been put forward such as drug resistance and declining vector control measures. For example, Hay et al. (2002) reported that the increases in malaria incidence in East Africa were taking place without clear evidence of a warming trend. However, recent studies (e.g., Chaves and Koenraadt (2010), Stern et al. (2011)) using updated datasets for the same locations did find evidence of a significant warming trend. The observed rise in annual temperatures has been linked with increasing malaria, for example, in the Usambara Mountains, Tanzania (Matola et al. 1987). Likewise, several more recent modeling studies (Teklehaimanot et al. 2004; Zhou et al. 2004; Abeku et al. 2004; Pascual et al. 2006) have investigated the role of climatic changes in observed increases in malaria risk as well. Chaves and Koenraadt (2010) concluded that, even though these studies each applied different modeling approaches and techniques, they all show an association between malaria and climate variables, making the linkage between climate change and malaria in the highlands of Africa rather robust. In the same publication, they argue, however, that overemphasizing the role of climate as the autonomous main driver of highland malaria does not account for the clear multifactorial causality of disease transmission.

The highlands are a fragile ecosystem under great pressure from increasing populations, deforestation, and increased farming (McMichael 2003). East African highlands are one of the most populated regions in Africa, and their population growth rates are among the highest in the world. As a result, the regions are also faced with high rates of poverty. Poverty and demographic pressures have spurred massive land use and land cover changes 
(including massive deforestation) for agricultural practices (Himeidan and Kweka 2012). The upland communities are often remote from regional health centers, and health services are patchy, making the surveillance and control of malaria difficult. It is increasingly acknowledged that the risk of highland malaria moving to higher altitudes depends on the interplay between climate change and, for example, land use change, population growth, population movement, agricultural practice (e.g., pesticide use, irrigation systems), cessation of malaria control activities, drug resistance, and socioeconomic status (McMichael and Woodruff 2005; Hales and Woodward 2003). For example, a study in Rwanda found that increases in temperature and rainfall were associated with a steep rise in malaria cases (Loevinsohn 1994). The increase in malaria was greater at higher altitudes than at lower altitudes. What is surprising about this study is that the difference in altitude between the high and low villages was only $100 \mathrm{~m}$, which may reflect a temperature difference of only $0.6{ }^{\circ} \mathrm{C}$ between the two sites (Linacre 1992). Such a small difference might suggest that in this instance factors, other than temperature, were also favoring transmission and malaria invasion of the highlands. For example, the limited immunity of people living at higher altitudes could have played a role. Additionally, malaria invasion of the African highlands has been associated with the migration of people from the lower areas to the higher altitudes (Lindsay and Martens 1998), introducing the malaria parasite into highland regions. Furthermore, the massive deforestation in East Africa has shown to be associated with changes in the local climate. As such, both the land use changes and global warming may act together in causing the observed regional change in the local climate of the East African highlands (Himeidan and Kweka 2012). Changes in crop choice can also play a role, as demonstrated by the invasion of malaria in the Bure highlands of Ethiopia due to the fact that the mosquito vector thrived on feeding on maize pollen, just shortly after this crop was introduced (Ye-Ebiyo et al. 2000; Kebede et al. 2005). Irrigation activities and forest clearing have been associated with increases in vector densities due to, for example, enhancing mosquito breeding sites (Himeidan and Kweka 2012). Susceptibility to the increasing mosquito densities and associated malaria risk is further complicated by the high poverty rates in the East Africa highlands. Fortunately, the highlands have experienced a reduction in malaria prevalence since the early 2000s, due to ongoing malaria interventions (Stern et al. 2011; Chaves and Koenraadt 2010; Himeidan and Kweka 2012). However, the sustainability of these interventions may be questioned (Himeidan and Kweka 2012). African countries mostly rely on external donors, and global funding levels for malaria are in an increasingly precarious state (Pigott et al. 2012); weakening of malaria control programs has been an important driver of observed past causes of malaria resurgence (Cohen et al. 2012).

A recent report by the Africa Initiative (Tesi 2011) stressed the multicausality of malaria; although climate change has been associated with the observed malaria invasion in African highlands, other factors are involved as well in accelerating this process. The report argues that climatic factors (increases in temperature, rainfall, and humidity) act as primary factors, because as long as the disease transmission is constrained by climatic factors, the disease will automatically be limited as well. The secondary factors, such as drug resistance, agricultural development, population growth, migration, conflicts, and land use change, can accelerate this process put in motion by climatic factors. Similarly, Chaves and Koenraadt (2010) emphasize that 'a multidimensional array of underlying factors is likely to be at play here, most of which may be sensitive to climatic change.' Hence, although climate change is believed to primarily affect the intrinsic malaria transmission potential (Cohen et al. 2012; Tesi 2011), it interacts with other factors and 
developments that affect disease dynamics as well. Most of them are expected to be affected by climate change, such as agriculture, foods security, migration, and poverty (IPCC 2007a; McMichael et al. 2012). Recently, Artzy-Randrup et al. (2010) hypothesized that the influence of climate change on malaria also interacts with the spread of drug resistance through altered levels of transmission intensity.

Parkes et al. (2005), among others, plea for new system-based approaches to address communicable diseases. They argue that the worldwide (re)emergence of infectious diseases demonstrates that the rate and scale of global change expose serious limitations of approaches that fail to engage with the wider contexts from which infectious diseases emerge. As Berrang-Ford et al. (2009) state, 'climate change is one of several determinants of infectious disease occurrence, whose impact is superimposed upon, and moderated by, parallel changes in non-climate determinants.'

\section{Conclusion}

Climate change impacts on our health are driven by a network of interactions among a diversity of developments. As vulnerability to climate change is both hazard and context dependent (IPCC 2007a), climate change should not be seen as 'a stand-alone risk factor,' but as a potential amplifier of important health and food security risks. Due to their particular vulnerability context, the health effects of climate change are expected to be especially harsh in the developing countries. Climate change could exacerbate climatesensitive hurdles to sustainable development faced by developing countries (IPCC 2007a), in particular with regard to important MDGs related to malaria and malnutrition (Kreft et al. 2010). This is not only due to differential exposure to the hazard, but also due to the interactions between climate and non-climate factors that fundamentally shape the high vulnerability of developing countries' populations to the anticipated health impacts. We need to be moving away from the discussion about the relative importance of climate change to other stressors, toward approaches that take possible synergies between different developments into account. Although this paper mainly focuses on food security and malaria risk in developing countries, the need for a systems approach is equally valid for other health impacts (e.g., heat waves, flooding, health impacts related to water scarcity) as well for more developed regions.

It is becoming widely acknowledged that, in addition to measures to mitigate greenhouse gas emissions, adaptation to climate change is necessary to avoid unacceptable impacts of anthropogenic climate change (IPCC 2001). The World Bank (2010) has estimated-assuming a $2{ }^{\circ} \mathrm{C}$ temperature increase- that climate change adaptation in the developing world will cost between $\$ 70$ and $\$ 100$ billion a year over the next 40 years. Under Article 4 of the United Nations Framework Convention on Climate Change (UNFCCC), developed countries are required to assist developing countries that are 'particularly vulnerable' to climate change in meeting costs of adaptation to its adverse effects (UN 1992). Hence, adaptation ranked high on the developing countries' agendas for the recent 18th conference of parties (COP18) to the UNFCCC in Doha (26 November-7 December 2012). Of particular importance were the discussions about the 'Green Climate Fund,' which aims to administer billions of dollars for developing nations for mitigation and adaptation (UN 2012a). The Green Climate Fund was launched in 2011 at COP17 in Durban. However, real progress on establishing this fund is lacking, and many details-including those related to the adaption committee to oversee 
adaptation activities in developing regions-still have to be worked out (Padma et al. 2011). In Doha, the procedural aspects of the Green Climate Fund were further discussed in order to make the fund operational as soon as possible, but no agreement on specific funding targets or benchmarks was reached (UNFCCC 2013). Of course, making funds for adaptation available is an important first step. What we know about adaptation, however, is limited, and we need to ask ourselves the question what such adaptation policies and projects should look like.

There are two broad categories of approaching adaptation in a developing context. The first is characterized by a somewhat narrow focus on managing the risks of specific climate impacts. However, effectively managing the health risks of climate change requires a broader understanding of the complex system interactions involved (Ebi 2011). In order to avoid an escalation of health risk synergies in the developing world, there is a need to better understand the multifaceted and complex linkages involved. It needs to be acknowledged that non-climate processes and stresses interact with climate change, determining the overall vulnerability to climate impacts. As such, adaptation measures have to be specific for the local context. Hence, the second approach adopts more of a 'vulnerability perspective,' seeking to address the causes of higher vulnerability and lower adaptive capacity by focussing on measures to reduce poverty and other non-climatic factors that make people vulnerable. This second approach has also spurred increasing attention for mainstreaming climate adaptation into development policies (Mertz et al. 2009). Such mainstreaming has, for example, been taken up by the Poverty-Environment Initiative, a joint initiative between the United Nations Development Programme (UNDP) and the United Nations Environment Programme (UNDP and UNEP 2011). However, efforts to mainstream climate change adaptation into development planning in order to reduce local vulnerabilities are still at a relatively early stage in many countries (UNDP and UNEP 2011).

Additionally, it needs to be recognized that local communities have traditional and local knowledge about their particular vulnerability context that may help them to better adapt to the impacts of global warming. For example, a recent paper by Nzeadibe et al. (2012) demonstrated that farmers in Nigeria were well aware of the changing climate conditions and - in response- - have been practicing some innovative indigenous measures for climate change adaptation for several years. Hence, adaptation should aim to strengthen these local coping mechanisms and facilitate the transfer of this type of local knowledge. The UNFCCC acknowledges that community-based adaptation can greatly benefit from knowledge of local coping strategies. For example, its secretariat has established a 'local coping strategies database' to facilitate the transfer of climate adaptation strategies and knowledge from one community to the other (UNFCCC 2012).

To conclude, reducing vulnerability is a legitimate goal of sustainable development (Adger and Winkels 2007) and adaptation is a key factor that will shape the future severity of climate change health impacts. Developing countries have specific needs for adaptation due to higher vulnerabilities (Mertz et al. 2009). Recognizing the interdependencies between factors that create this high vulnerability is central in formulating adequate adaptation policies and sustainable development (Adger and Winkels 2007). A sound response to climate change health risks should take a systems approach toward adaptation, acknowledging the importance of the (local) vulnerability context. Without efforts to improve our understanding of this system and subsequent action to protect the most vulnerable, the amplification of (other) existing and emerging health risks might become the greatest tragedy of climate change. 


\section{References}

Abeku, T., De Vlas, S., Boorsboom, G., Tadege, A., Gebreyesus, Y., Gebreyohannes, H., et al. (2004). Effects of meteorological factors on epidemic malaria in Ethiopia: A statistical modelling approach based on theoretical reasoning. Parasitology, 128, 585-593.

Adger, W., \& Winkels, A. (2007). Vulnerability, poverty and sustaining well-being. In G. Atkinson, S. Diets, \& E. Neumayer (Eds.), Handbook of sustainable development. Cheltenham: Elgar.

Ainsworth, E., \& Ort, D. (2010). How do we improve crop production in a warming world? Plant Physiology, 154, 526-530.

Albrecht, G., Freeman, S., \& Higginbothman, N. (1998). Complexity and human health: The case for a transdisciplinary paradigm. Culture, Medicine and Psychiatry, 22, 55-92.

Artzy-Randrup, Y., Alonso, D., \& Pascual, M. (2010). Transmission intensity and drug resistance in malaria population dynamics: Implications for climate change. PLoS One, 5, e13588.

Arya, N., Howard, J., Isaacs, S., McAllister, M., Murphy, S., Rapport, D., et al. (2009). Time for an ecosystem approach to public health? Lessons from two infectious disease outbreaks in Canada. Global Public Health, 4, 31-49.

Berrang-Ford, L., Maclean, J., Gyorkos, T., Ford, J., \& Ogden, N. (2009). Climate change and malaria in Canada: A systems approach. Interdisciplinary Perspectives on Infectious Diseases, 2009. Article ID 385487,385413 pages.

Brown, M., \& Funk, C. (2008). Food security under climate change. Science, 319, 580-581.

Canfalonieri, U., \& McMichael, A. J. (Eds.). (2006). Global environmental change and human health: Science plan and implementation strategy: Earth System Science Partnership (ESSP report no. 4).

Chaves, L., \& Koenraadt, C. (2010). Climate change and highland malaria: Fresh air for a hot debate. Quarterly Review of Biology, 85, 27-55.

Ciais, P., Reichstein, M., Viovy, N., Granier, A., Ogee, J., Allard, V., et al. (2005). Europe-wide reduction in primary productivity caused by the heat and drought in 2003. Nature, 437, 529-534.

Cohen, M. (2000). Changing patterns of infectious disease. Nature, 406(6797), 762-767.

Cohen, J., Smith, D., Cotter, C., Ward, A., Yamey, G., Sabot, O., et al. (2012). Malaria resurgence: A systematic review and assessment of its causes. Malaria Journal, 11, 122.

Colwell, R. R. (2004). Biocomplexity and a new public health domain. EcoHealth, 1, 6-7.

Comrie, A. (2007). Climate change and human health. Geography Compass, 1, 323-339.

Costello, A., Abbas, M., Allen, A., Ball, S., Bell, S., Bellamy, R., et al. (2009). Managing the health effects of climate change. Lancet, 373, 1693-1733.

Ebi, K. (2009). Managing the changing health risks of climate change. Current Opinion in Environmental Sustainability, 1, 107-110.

Ebi, K. (2011). Climate change and health risks: Assessing and responding to them through' adaptive management'. Health Affairs, 30, 924-930.

Ebi, K., Berry, P., Campbell-Lendrum, D., Corvalan, C., \& Guillemot, J. (2011). Protecting health from climate change: Vulnerability and adaptation assessment. World Health Organization and PanAmerican Health Organization.

Ermert, V., Fink, A., Morse, A., \& Paeth, H. (2012). The impacts of regional climate change on malaria risk due to greenhouse gas forcing and land-use changes in tropical Africa. Environmental Health Perspectives, $120,77-84$.

FAO. (1996a). Food and international trade. Rome: Food and Agricultural Organization of the United Nations.

FAO. (1996b). Rome declaration on world food security. Rome: Food and Agriculture Organization.

FAO. (2003a). The state of food insecurity in the world 2003. Rome: Food and Agricultural Organization of the United Nations.

FAO. (2003b). Trade reforms and food security: Conceptualizing the linkages. Rome: Food and Agricultural Organization of the United Nations.

FAO. (2008). Soaring food prices: Facts, perspectives, impacts and actions required. The Food and Agricultural Organization of the United Nations. High-level conference on world food security: The challenges of climate change and bioenergy. Rome June 3-5, 2008.

FAO. (2009a). How to feed the world in 2050? Issues brief. High-level expert forum, Rome, 12-13 October 2009. Available at http://www.fao.org/fileadmin/templates/wsfs/docs/expert_paper/How_to_Feed_ the_World_in_2050.pdf. Accessed 22 August, 2012.

FAO. (2009b). The state of agricultural commodity markets: High food prices and the food crisis- experiences and lessons learned. Rome: Food and Agricultural Organization of the United Nations.

FAO. (2010). The state of food insecurity in the world 2010. Rome: Food and Agricultural Organization of the United Nations. 
FAO. (2011a). Climate change and food security in the context of the Cancun agreements. Submission by the Food and Agricultural Organization of the United nations to the 14th session of the UNFCCC's Ad Hoc Working Group on Long-Term Cooperative Action Under the Convention, in accordance with paragraph 1 of the Bali Action Plan.

FAO. (2011b). The state of food insecurity in the world 2011. Rome: Food and Agricultural Organization of the United Nations.

Gething, P., Smith, D., Patil, A., Tatem, A., Snow, R., \& Hay, S. (2010). Climate change and the global malaria recession. Nature, 465, 342-345.

Gezondheidsraad. (2009). Mondiale milieu-invloed op onze gezondheid. Den Haag: Gezondheidsraad; publicatienr: 2009/15.

Hales, S., \& Woodward, A. (2003). Climate change will increase demands on malaria control in Africa. The Lancet, 362, 1775-1776.

Hammond, R., \& Dubé, L. (2012). A systems science perspective and transdisciplinary models for food and nutrition security. PNAS,. doi:10.1073/pnas.0913003109.

Hay, S., Rogers, D., Randolph, S. E., Stern, D., Cox, J., Shanks, G., et al. (2002). Hot topic or hot air? Climate change an malaria resurgence in East African highlands. Trends in Parasitology, 18, 530-534.

Heady, D., \& Fan, S. (2008). Anatomy of a crisis: The causes and consequences of surging food prices. Washington, DC: International Food Policy Research Institute.

Himeidan, Y., \& Kweka, E. (2012). Malaria in East African highlands during the past 30 years: Impact of environmental changes. Frontiers in Physiology, 3, Article 315.

HLPE. (2012). Food security and climate change. Rome: A report by the High Level Panel of Expertise on Food Security and Nutrition of the Committee on World Food Security.

Howden, S., Soussana, J., Tubiello, F., Chhetri, N., Dunlop, M., \& Meinke, H. (2007). Adapting agriculture to climate change. Proceedings of the National Academy of Sciences USA, 104, 19691-19696.

Huynen, M. M. T. E. (2008). Future health in a globalising world. Maastricht: Universitaire Pers Maastricht.

Huynen, M. M. T. E., Martens, P., \& Hilderink, H. B. M. (2005a). The health impacts of globalisation: A conceptual framework. Globalization and Health, 1, article number 14 (12 pages).

Huynen, M. M. T. E., Martens, P., \& Hilderink, H. B. M. (2005b). The health impacts of globalisation: A conceptual framework. Bilthoven: Netherlands Environmental Assessment Agency (MNP-RIVM).

Iglesias, A., Quiroga, S., \& Diz, A. (2011). Looking into the future of agriculture in a changing climate. European Review of Agricultural Economics, 38, 427-447.

IPCC. (2000). Special report on emission scenarios. Cambridge: Cambridge University Press.

IPCC. (2001). Climate change 2001: Impacts, adaptation and vulnerability. Cambridge: Cambridge University Press.

IPCC. (2007a). Climate change 2007: Impacts, adaptation and vulnerability. Cambridge: Cambridge University Press.

IPCC. (2007b). Climate change 2007: The scientific basis. Cambridge: Cambridge University Press.

Kebede, A., McCann, J., \& Ye-Ebiyo, Y. (2005). New evidence of the effects of agro-ecological change on malaria transmission. American Journal of Tropical Medicine and Hygiene, 73, 676-680.

Kreft, S., Harmeling, S., Bals, C., Zachher, W., \& van de Sand, L. (2010). The Millennium Development Goals and climate change: Taking stock and looking ahead. Bonn: Germanwatch.

Ladd, B. D., \& Soskolne, C. L. (2008). A toolkit for ecoepidemiological enquiry under global ecological change. In C. L. Soskolne, L. Westra, L. J. Kotze, B. Mackey, W. E. Rees, \& R. Westra (Eds.), Sustaining life on earth: Environmental and human health through global governance. Lanham: Lexington Books.

Lang, T. (1996). Food security: Does it conflict with globalisation? Development, 4, 45-50.

Linacre, E. (1992). Climate data and resources: A reference and guide. London: Routeledge.

Lindsay, S., \& Martens, W. (1998). Malaria in the African highlands: Past, present and future. Bulletin of the World Health Organization, 76, 33-45.

Lobell, D., \& Field, C. (2007). Global scale climate-crop yield relationships and the impact of recent warming. Environmental Research Letters, 2, 014002.

Loevinsohn, M. (1994). Climatic warming and increased malaria incidence in Rwanda. The Lancet, 434, 714-718.

Long, S., Ainsworth, E., Leakey, A., Nosberger, J., \& Ort, D. (2006). Food for thought: Lower-thanexpected crop yield stimulation with rising $\mathrm{CO}_{2}$ concentrations. Science, 312, 1918-1921.

Martens, W. (1998). Health impacts of climate change and ozone depletion: An ecoepidemiologic modeling approach. Environmental Health Perspectives, 106(Suppl 1), 241-251.

Martens, P., Kovats, R., Nijhof, S., de Vries, P., Livermore, M., \& Bradley, D. (1999). Climate change and future populations at risk of malaria. Global Environmental Change, S89-S107. 
Martens, W., Niessen, L., Rotmans, J., Jetten, T., \& McMichael, A. (1995). Potential impact of global climate change on malaria risk. Environmental Health Perspectives, 458-464.

Martens, P., \& Thomas, C. (2005). Climate change and malaria risk: Complexity and scaling. In W. Takken, P. Martens, \& R. Bogers (Eds.), Environmental change and malaria risk: global and local implications. Dordrecht: Springer.

Matola, Y., White, G., \& Magayuka, S. (1987). The changed pattern of malaria endemicity and transmission at Amani in the eastern Usambara mountains, north-eastern Tanzania. Journal of Tropical Medicine Hygiene, 90, 127-134.

McLaren, L., \& Hawe, P. (2005). Ecological perspectives in health research. Journal of Epidemiology and Community Health, 59, 6-14.

McMichael, A. J. (1995). The health of persons, populations and planets: Epidemiology comes full circle. Epidemiology, 6, 633-636.

McMichael, A. J. (1999). Prisoners of the proximate: Loosening the constraints on epidemiology in an age of change. American Journal of Epidemiology, 10, 887-897.

McMichael, A. J. (2003). Global climate change: Will it affect vector-borne infectious disease. Internal Medicine Journal, 33, 554-555.

McMichael, A. J. (2004). Environmental and social influences on emerging infections: Past, present, and future. Philosophical Transactions of the Royal Society, 359(1447), 1049-1058.

McMichael, A. J. (2005). Detecting the health effects of environmental change: Scientific and political challenge. EcoHealth, 2, 1-3.

McMichael, C., Barnett, J., \& McMichael, A. (2012). An ill wind? Climate change, migration and health. Environmental Health Perspectives, 120, 646-654.

McMichael, A., Campbell-Lendrum, D., Corvalan, C., Ebi, K., Githeki, A., Scheraga, J., et al. (Eds.). (2003). Climate change and human health: Risks and responses. Geneva: World Health Organization.

McMichael, A. J., Campbell-Lendrum, D., Kovats, R. S., Edwards, S., Wilkonson, P., Wilson, T., et al. (2004). Global climate change. In M. Ezzati, A. D. Lopez, A. Rodgers, \& C. J. L. Murray (Eds.), Comparative quantification of health risks. Geneva: World Health Organization.

McMichael, A. J., \& Woodruff, R. (2005). Detecting the health effects of environmental change: Scientific and political challenge. EcoHealth, 2, 1-3.

McMichael, A. J., Woodruff, R., \& Hales, S. (2006). Climate change and human health: Present and future risks. The Lancet, 367, 859-869.

Mertz, O., Halsnaes, K., Olesen, J., \& Rasmussen, K. (2009). Adaptation to climate change in developing countries. Environmental Management, 43, 743-752.

Morris, G. (2010). Ecological public health and climate change policy. Perspectives in Public Health, 130, $34-40$.

Morse, S. (1995). Factors in the emergence of infectious diseases. Emerging Infectious Diseases, 1(1), 7-15.

Murray, C., Rosenfeld, L., Lim, S., Andrews, K., Foreman, K., Haring, D., et al. (2012). Global malaria mortality between 1980 and 2010: A systematic analysis. Lancet, 379, 413-431.

Nellemann, C., MacDevette, M., Manders, T., Eickhout, B., Svihus, B., Prins, A., et al. (2009). The environmental food crisis: The environment's role in adverting future food crises- a UNEP rapid response assessment. United Nations Environmental Programme.

Nzeadibe, T., Egbule, C., Chukwuone, N., Agwu, A., \& Agu, V. (2012). Indigenous innovations for climate change adaptation in the Niger Delta region of Nigeria. Environment, Development and Sustainability, 14, 901-914.

Padma, T., Bafana, B., \& Nordling, L. (2011). Climate deal leaves questions on green fund and tech transfer. Nature News Comment. Publication date December 13, 2011. http://www.nature.com/news/climatedeal-leaves-questions-on-green-fund-and-tech-transfer-1.9638. Last accessed November 12, 2012.

Parkes, M. W., Bienen, L., Breilh, J., Hsu, L., McDonald, M., Patz, J. A., et al. (2005). All hands on deck: transdisciplinary approaches to emerging infectious disease. EcoHealth, 2, 258-272.

Pascual, M., Ahumada, J., Chaves, L., Rodo, X., \& Bouma, M. (2006). Malaria resurgence in the east African highlands: Temperature trends revisited. Proceedings of the National Academy of Sciences USA, 103, 5829-5834.

Pearce, N. (2004). The globalization of epidemiology: Introductory remarks. International Journal of Epidemiology, 33, 1-5.

Pearce, N., \& Merletti, F. (2006). Complexity, simplicity, and epidemiology. International Journal of Epidemiology, 35, 515-519.

Pigott, D., Atun, R., Moyes, C., Hay, S., \& Gething, P. (2012). Funding for malaria control 2006-2010: A comprehensive global assessment. Malaria Journal, 11, 246.

RBM Partnership (2008). The global malaria action plan: For a malaria-free world. Geneva: Roll Back Malaria Partnership, World Health Organization. 
Ricci, F. (2012). Social implications of malaria and their relationships with poverty. Mediterranean Journal of Hematology and Infectious Diseases, 4, e2012048.

Rogers, D. J., \& Randolph, S. E. (2000). The global spread of malaria in a future, warmer world. Science, 289, 1763-1765.

Schmidhuber, J., \& Tubiello, F. (2007). Global food security under climate change. PNAS, 104, 19703-19708.

Soskolne, C., \& Broemling, N. (2002). Eco-epidemiology: On the need to measure health effects from global change. Global Change \& Human Health, 3(1), 58-66.

Soskolne, C., Butler, C., Ijsselmuiden, C., London, L., \& von Schirnding, Y. (2007). Toward a global agenda for research in environmental epidemiology. Epidemiology and Society, 18(1), 162-166.

Stern, D., Gething, P., Kabaria, C., Temperly, W., Noor, A., Okiro, E., et al. (2011). Temperature and malaria trends in Highland East Africa. PLOS ONE, 6, e24524.

Susser, M., \& Susser, E. (1996). Choosing a future for epidemiology: II. From black box to Chinese boxes and eco-epidemiology. American Journal of Public Health, 86, 674-677.

Sutherst, R. (2004). Global change and human vulnerability to vector-borne diseases. Clinical Microbiology Reviews, 17(1), 136-173.

Teklehaimanot, H., Lipsitch, M., Kteklehaimanot, A., \& Schwartz, J. (2004). Weather-based prediction of Plasmodium falciparum malaria in epidemic-prone regions in Ethiopia. I. Patterns of lagged weather effects reflect biological mechanisms. Malaria Journal, 3, 41.

Tesi, M. (2011). Global warming and health: The issue of malaria in Eastern Africa's highlands. Africa initiative Discussion papers no. 2- August 2011. Africa Initiative and the Centre for International Governance Innovation.

Tubiello, F., \& Fischer, G. (2006). Reducing climate change impacts on agriculture: Global and regional effects of mitigation, 2000-2080. Technological Forecasting and Social Change,. doi:10.1016/j.techfore. 2006.1005.1027.

UN. (1992). United Nations Framework Convention on Climate Change. http://unfccc.int/resource/ docs/convkp/conveng.pdf. Last accessed November 12, 2012.

UN. (2009). UN general assembly panel discussion. Food production must double by 2050 to meet demand from world's growing population. United Nations.

UN. (2012a). Green Climate Fund. http://unfccc.int/cooperation_and_support/financial_mechanism/ green_climate_fund/items/5869.php. Last accessed November 12, 2012.

UN. (2012b). The Millennium Development Goals report 2012. New York: Unite Nations.

UNDP, \& UNEP. (2011). Mainstreaming climate change adaptation into development planning: A guide for practitioners. UNDP-UNEP poverty-environment initiative.

UNFCCC. (2012). Database on local coping strategies. United Nations Framework Convention on Climate Change. http://maindb.unfccc.int/public/adaptation/. Last accessed November 12, 2012.

UNFCCC. (2013). Report of the Conference of the Parties on its eighteenth session, held in Doha from 26 November to 8 December 2012-Decision 6/CP.18. Report of the Green Climate Fund to the Conference of the Parties and guidance to the Green Climate Fund United Nations Framework Convention on Climate Change.

USGCRP. (2008). Analyses of the effects of global change on human health and welfare and human systems (SAP 4.6). Washington, DC: Environmental Protection Agency.

van Lieshout, M., Kovats, R., Livermore, M., \& Martens, P. (2004). Climate change and malaria: Analysis of the SRES climate and socio-economic scenarios. Global Environmental Change, 14, 87-99.

WB. (2010). The economics of adaptation to climate change: Synthesis report. Washington, DC: The World Bank.

WHO. (2002). The world health report 2002: Reducing risks, promoting healthy life. Geneva: World Health Organization.

WHO. (2009). Systems thinking for health systems strengthening. Geneva: World Health Organization.

WHO. (2011). World malaria report 2011. Geneva: World Health Organization.

Wilcox, B., \& Colwell, R. (2005). Emerging and reemerging infectious diseases: Biocomplexity as an interdisciplinary paradigm. EcoHealth, 2, 244-257.

World Bank. (2009). World development report 2010: Development and climate change. Washington, DC: World Bank.

Ye-Ebiyo, Y., Pollcak, R., \& Spielman, A. (2000). Enhanced development in nature of larval Anopheles arabiensis mosquitoes feeding on maize pollen. American Journal of Tropical Medicine and Hygiene, 63, 90-93.

Zhou, G., Minakawa, N., Githeko, A., \& Yan, G. (2004). Association between climate variability and malaria epidemics in the East African highlands. Proceedings of the National Academy of Sciences USA, 101, 2375-2380. 